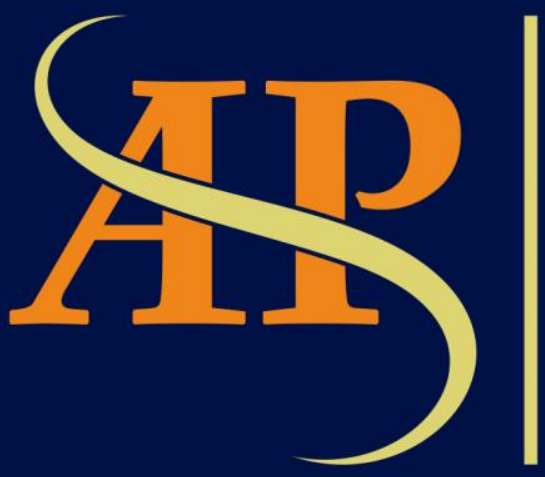

JURNAL

ASIA

PACIFIC STUDIES

Journal of International Relations Study Program Faculty of Social and Political Sciences Universitas Kristen Indonesia

Volume 2 | Number 1 | January - June 2018 


\title{
THE IMPLEMENTATION OF AUSTRALIA'S MARITIME DEFENSE STRATEGY IN RESPONSE TO CHINA'S MILITARY MODERNIZATION IN THE INDO-PACIFIC REGION (2013-2016)
}

\author{
${ }^{1}$ Isti Marta Sukma, ${ }^{2}$ Anak Agung Banyu Perwita \\ ${ }^{12}$ International Relations, President University, Jl Ki Hajar Dewantara Cikarang, West Java 17550 \\ ${ }^{1}$ istimartasukma@gmail.com \\ 2 aabanyu.perwita@gmail.com
}

\begin{abstract}
Along with economic development of a country, the sphere of the national interests are automatically cultivates. China, with the rapid economy development, has been undergoing military modernization in order to protect their national interests better. Indo-Pacific region as one of the most crucial region in the world, dynamically, has been evolved into major powers countries' favorite region particularly the maritime sector. Australia, which located inside the Indo-Pacific region as well as the one that puts most of the national interests in the region, has been aware that China's military modernization can not be fully perceived as "peaceful rise" due to uncertain future circumstances. The purpose of this research is to examine the maritime defense strategy response of Australia regarding China's military modernization in Indo-Pacific region. This research provides further explanation regarding Australia's standpoint in Indo-Pacific region, China's military modernization and the sphere of influence in Indo-Pacific, and most importantly-the analysis of Australia's implementation of the maritime defense strategy in responding China's military modernization in the region.
\end{abstract}

Keywords: Maritime strategy, China's Military Modernization, Indo-Pacific, Defense Strategy, National Interests, Naval Power.

\begin{abstract}
Abstrak
Seiring dengan perkembangan ekonomi suatu negara, bidang kepentingan nasional berkembang secara otomatis. China, dengan perkembangan ekonomi yang pesat, telah menjalani modernisasi militer untuk melindungi kepentingan nasional mereka dengan lebih baik. Kawasan Indo-Pasifik sebagai salah satu wilayah paling krusial di dunia, secara dinamis, telah berkembang menjadi favorit negara-negara besar terutama untuk sektor maritimnya. Australia, yang berada di dalam wilayah Indo-Pasifik dan juga negara yang menempatkan sebagian besar kepentingan nasional di kawasan ini, telah menyadari bahwa modernisasi militer China tidak dapat sepenuhnya dianggap sebagai "pembangunan damai" karena keadaan masa depan yang tidak pasti. Tujuan dari penelitian ini adalah untuk menguji respons strategi pertahanan maritim Australia mengenai modernisasi militer China di wilayah Indo-Pasifik. Penelitian ini akan memberikan penjelasan lebih lanjut mengenai sudut pandang Australia di wilayah Indo-Pasifik, modernisasi militer China dan lingkungan pengaruhnya di Indo-Pasifik, dan yang paling penting - analisis implementasi strategi pertahanan maritim Australia dalam menanggapi modernisasi militer China di wilayah tersebut.
\end{abstract}

Kata kunci: Maritim Australia, Modernisasi Militer China, Indo-Pasifik, Strategi Pertahanan, Minat Nasional, Kekuatan Angkatan Laut. 


\section{Introduction}

China has grown as the world's second largest economy in the last decades and still undergoing a critical change of reform as well as continuing its stunning development. China believes with its peaceful growth, a prosperous and stable world will provide more opportunities for China to pursue an independent of peaceful foreign policy and a national defense policy in which according to its defensive in nature, opposing the idea of hegemonies and power politics in all forms (China's MOD 2014). China claimed that hegemony and expansion are not the things they are trying to pursue since China believes that the other nations in the world created as much strategic certainties for China. It has also stated in China's defense white paper that China is aware of the existence of more diverse and complex security challenges substantially the vast territories and territorial seas (CSIS 2013).

The end of the Cold War and the collapse of USSR have encouraged China to embrace its diplomatic and expand its sphere of influence in the world. It is true that a massive economic development will automatically lead to military modernization. China's quality of weapons and military systems has initiated since the aftermath of the Cold War in 1991 and keeps largely increasing the phase of military modernization since then. China's economic development has supported their military modernization yet has formed China as a major power in Asia and The Pacific. Most experts believe that China will keep going on pursuing the substantial economic growth as well as continue to expand their military forces capability. China's long-term military programs are also affecting the development of the civil technology and scientific networks. China is evolving its military technology and defenserelated programs in the US, Russia, India, and other countries (Michael Rask 2013).

The fact that more than $70 \%$ of the Earth's surface is covered by water and the world's ocean connects all the globe's landmasses has made the importance of the sea as an international reality, one with particular significance for Australia as an island nation surrounded by huge maritime resource zones (AUS Maritime Doctrine 2010). Indo-Pacific region has particularly emerged as the world's most dynamic geopolitical zone eversince the end of the Cold War. Indo-Pacific region has been a very important region in the world, and also is one of the most important maritime projections for China. As a result, Australia as one of the major powers in the region has been aware regarding the importance of securing the region. Australia as the biggest archipelago state and the smallest continent state in the world has also a big role and ambition to maximize their strategic environment strategy in order to pursue their national interests. The geographical condition mentioned has leaded the awareness of maritime security and the urgency to have the best maritime defense strategy for Australia. Australia's Navy power is undertaking significant introduction of new capabilities which will define it as an extremely nimble and capable force.

The growing trade, investment and energy flows across this broader region which is a significant trade routes pass are strengthening Australia's economic and security interdependencies (The Diplomat 2017). Australia's strategic geography generally determines the form and the expanse of their defense force. The economic, military, and political trends that appeared in Indo-Pacific region has created awareness for Australia to secure further the region and its maritime domain. Australia's national security depends to the geographical security and Australia is surrounded by a massive maritime domain.

In the 2013 Defense White Paper, Australia clearly discussed about Indo-Pacific region right in the starting point of the paper. "The Indo-Pacific is still emerging as a system. But over time, Australia's security environment will be significantly influenced by how the Indo-Pacific and its architecture evolves" (ADWP 2013).

The existence of China as one of the important actors in the region, with the military modernization that has been developing has effected Australia of their maritime defense 
policy. Evidently, in Australia's Defense White Paper that was published in 2016, Australia highlighted that the ongoing military modernization in the Indo-Pacific region as one of the six main keys that will shape Australia's security requirements (The Diplomat 2016). The white paper also accentuated the growth of China's military capability as the most significant regional military modernization.

"China's major goals of economic growth and political stability are reliant on the maintenance of regional security and stability in a larger extent. As China continues to engage as a major participant in the global economy and becomes increasingly reliant on overseas energy resources, it has a growing stake in regional peace and stability" (Australia's Parliament 2004, 6.2)

As has been implied in the above quotations, this paper discusses the maritime defense strategy response of Australia regarding China's military modernization in Indo-Pacific region. It provides further explanation regarding Australia's standpoint in Indo-Pacific region, China's military modernization and the sphere of influence in Indo-Pacific, and most importantly - the analysis of Australia's implementation of the maritime defense strategy in responding China's military modernization in the region.

\section{Australia Outlook: The Dynamic of Strategic Environment in Indo-Pacific Region}

The concept of Indo-Pacific region is an applicable array to comprehend the changing of regional dynamics. This concept examines the developing interactions among major East Asian Powers and the economies, strategic implications, particularly in the maritime realm. This concept is not necessarily deliberated to replace the Asia-Pacific concept, but simply emphasizing for certain purposes to contemplate a broader geographic area and set of interactions. The Indo-Pacific region concentrates on the growing interactions both in terms of economic and strategy from Korean Peninsula to the Persian Gulf and centered by South-East Asia (Policy Forum 2016).

Historically, Australia's first acknowledgment towards Australia's strategic geography was the vulnerabilities of Australia's northern approaches and the urge to move the focus of Australian Defense Force (ADF) from the South-East to the North-West. Both economic and technology development did influence Australia's strength and vulnerabilities in terms of geographical strategy. Australia's primary strategic concerned the area from the mid-Indian Ocean to mid-Pacific - from Southeast Asia and South China Sea to Antartica (Paul Dibb 2006).

In Australia's Defense White Paper 2016, Australia has continued the highlight towards Indo-Pacific region, this time namely "A stable Indo-Pacific region and a rules-based global order" under the chapter 3: Australia's Defense Strategy. Australia emphasized that Indo-Pacific region was considered as their third Strategic Defense Interest, with a stable rules-based regional order to protect the trade lane-as what Australia has mentioned in 2013 - and to secure the risk of instability and compulsion that would influence Australia's interests (ADWP 2016).

Australia also explained that China's economic development has changed the balance of regional global strategic and it was also a big contributor towards the weight shifting in the Indo-Pacific region. Along with the economic growth, China's defense capabilities are also growing - and military is modernized as the result. With the development of China's global interests, China is predicted to become more active in international issues on a wider scale, yet, stated this point afterwards: "Military modernization in our region, however, reduces these geographic advantages. Potential adversaries may have capabilities that can reduce the 
protection provided by distance and thereby reduce our early warning and mobilization timeframe" (ADWP 2013)

In 2016, Australia has emphasized several points in the Defense White Paper-that directly addressed to China's military modernization particularly in Indo-Pacific region as follows: "The growth of China's national power, including its military modernization, means China's policies and actions will have a major impact on the stability of the Indo-Pacific," (ADWP 2016)

At first, Australia emphasized that military modernization in the Indo-Pacific region is completely normal and it is underpinned the positive economic changes in the region. Australia was also briefly explained regarding the military spending in Asia which grew 0.6 $\%$, reached around $\$ 386$ billion in total has increased even higher than Europe's. The most important is the point where Australia puts the importance of stability in Indo-Pacific region and rules-based order. As the third strategic defense interests of Australia, Australia ensured that rules-based order will support Australia in pursuing their national interests in the region. These rules covered the open, free, and secure trading system in the region and minimizing the risk that would give disadvantages towards Australia's interests (ADWP 2016).

\section{China's Military Modernization and Sphere of Influence in the Indo-Pacific Region (2013-2016)}

In the third annual general meeting of the Communist Party declared that they should order to optimize the army's size and structure, to adjust the balance among the service and to reduce the non-combat institute and personnel. People's Liberation Army Navy (PLAN) has 10 percent of the personnel distribution. Two years after that, in 2015, Xi Jinping called for 300,000 reductions to bring the force into 2 million. Next months afterwards, China proclaimed a crucial change in PLA order and commands. China kept undergoing the military reformation with rapid growth comparing what had been anticipated in few years back. The inference of the military power that credibly changed still remains far from clear (Joshi M 2017).

China's commitment and strategic choice to take the aim of peaceful development is defensive in nature. China resisted all kind of hegemonies or power politics and emphasized that China will not behave in hegemonic manner, nor will engage in military expansion. China is more concerned regarding the new concept of security that shows mutual trust and benefit, as well as balance and coordination in common and cooperative security (Information Office of the State Council the People's Republic of China 2013).

China has borderline which is more than $22.000 \mathrm{~km}$ and $18.000 \mathrm{~km}$ coastline. As a country that has the longest border land, and most neighbors, China's armed forces have to defend and implement the jurisdiction over China's land border and seas. The importance of securing the borders and coastal areas are indeed not an easy task. The PLAN has to strengthen the control over maritime, build the patrol mechanisms, develop situational awareness in surrounding sea areas, securing the area from various kind of harassment, penetration, and sabotaging activities, as well as to maintain peace and the stability of the surrounding areas (Information Office of the State Council the People's Republic of China 2013).

The emergence of Indo-Pacific is indeed one of the most crucial elements of China's national interests. In 2015, China's Xi Jinping visited Washington DC to discuss the issues of South China Sea, yet more importantly - as the pattern of the region changed - to discuss the emergence of Indo-Pacific and its influence towards China's Maritime Silk Road strategy (Rany D. Mullen and Cody Poplin 2015). 
China established the idea of MSRI (Maritime Silk Road Initiative) in 2013. This initiative basically designed to go to China's coast to Europe crossing Indian Ocean, SouthChina Sea at once. It is also aim to establish a modern network of high-speed railways and ports stretching across South and Southeast Asia. This automatically supports ASEAN countries to build maritime development strategy in order to strengthen the regional relations. The initiative was proposed in Indonesia and in 2015 - in order to minimize ASEAN security concerns and in order to grow the mutual trust - China has successfully aligned with Indonesian President Joko Widodo vision of Indonesia as a global maritime axis to synergize China-Indonesia mutual interests in the region (Zhao Hong 2015).

Therefore there are three main differences among the revival of maritime and landbased Silk roast; there are numerous countries throughout the sea road to Europe and Indian Ocean countries are more populated than Central Asia, China's leadership has opened how far the concept will go, China has huge investment to the West and China's effort in Central Asia caused disapproval in Russia and Europe. The influence is growing from Western Pacific to the Middle East (Benhard Zand 2016).

Chinese government has released official figure that stated the defense budget of China in 2016 is at 954 billion yuan ( $\$ 146.6$ billion), increased 7.6 percent from the 2015 . In 2015 , China's defense budget was 887 billion yuan ( $\$ 144.2$ billion). While according to The Stockholm International Peace Research Institute (SIPRI), the defense budget of China is estimated the overall 2016 figure at $\$ 226$ billion and the 2015 estimate at $\$ 214$ billion. This data is also estimated by the other organizations as to what China spent on its military in 2015 vary. The U.S. Department of Defense (DOD) stated that in 2015 China's defense budget reached more than $\$ 180$ billion, while the International Institute for Strategic Studies (IISS) believes that China spent $\$ 193$ billion (CSIS 2017).

The national security concept itself as what has mentioned in the first chapter is the fundamental concept that subordinated the two theories mentioned in this thesis. National security concept will also help to examine the phraseology of the defense policy. This concept examines that state has to protect themselves against all matters that lead to "national crisis" throughout diplomacy, economic, political, and military. This concept implies on how to secure the state against external and internal threats in every national sphere and presume that the coerciveness of state is according to the preservation of territorial strength. Therefore, the national security is inevitable with the existence of threat perception.

Politically, aside from the defense and military operations other than war, PLA's basic role in Chinese Communist Party (CCP) is to be the military wing as well as become the rules-guarantee for one particular party. The relations among civil and military have encountered a big change from the previous symbiotic ties. By the end of 1980, a moderate divergent among civil and military followed the shift in civil and military leadership and the development of professionalization in PLA. Due to the higher specialization that PLA has, and the lesser representation they have in the party, PLA seems reduced the relevance compared to what they had in the past. PLA has also withdrawn from making non-military policy and has concentrated on making policy that related to defense and national security issues conservatively, as well as PLA has limited authority in the party particularly in technical sector (European Parliament 2015).

More than eighty percent of China's energy imports are crossing the Malacca strait. By this means, China needs to sustain their power to secure their foreign energy investments and defending their critical sea lanes from any kind of threats and disruption that has possibility to occur. The need of extended-range power projection such as the development of carriers and another maritime warfare and exercise are inevitable (Robert M. Gates 2008).

As some scholars believe that history can repeated itself, it is necessary to look upon China's historical background in order to understand whether or not there is a possibility for 
China to start an aggressive behavior that could probably occurred in the region. In the Second World War era, China had a huge protest that they considered themselves betrayed by Versailles treaty. China has contributed huge numbers of workers to the Allied in the First World War, and believed that if the Allied won the war it would be a great step to China to end the imperialism and to have their own national self-determination. The May Fourth movement was aiming to develop their politic, social, and culture that came to China (Jacob L. Shapiro 2016). China's fight against Japan was one of the biggest stories in the Second World War. Even though China was the first Allies power that was able to fight against Axis power, the story was somehow remained untold because of the belated annex to the battle in the Pacific theater. Japan invaded Manchuria at that time and finally provoked Chinese into full-scale war (Mitter R 2013). By these historical facts, this might also able to be the indication that China is naturally defensive and it is not an impossible thing for China to rise peacefully.

China is the most populated country in the world with the latest counted population as $1,285,688,988$ people. The rapid change the changes where China complexly interact with others and forced the two leadership as well as international community to imagine how likely to be in the future. Chinese success in economy has interpreted as the results of the hardworking culture of the people. Globalization has brought both opportunities and challenges to China, and China has faced poverty, inequality, and some violations in financial markets yet still standing foremost with the global determination (Sangit Sarita Dwivedi 2017).

In 2011, China's government has approved the Guangdong Province plan regarding the plan of establishing a national-level marine economic development. This plan indicated the strength of China's marine economic in $12^{\text {th }}$ five year plan. Along with the increase of regional competition in the maritime sector as well as the shipping lanes, the plan and the strategy leaps to impact the international community particularly in the region (East Asia Forum 2011).

In 2014, PLA Navy had 255,000 sailors; 1 aircraft carrier, 69 submarines; 29 destroyers; 49 frigates, 86 landing crafts, 39 minesweepers, and 368 coast defense ships (China Today 2014). In 2015, there were many speculations regarding China's military reform, since China's Xi declared the plan to cut 300,000 troops. This speculation has appeared since 2012 that many of military battle zones replaced. In Central Military Commission (CMC), China has successfully created 15 new departments with a complete transfer function. In a national operational effectivity, transition from the military battle zone to the battle zone is very important for the joint cooperation capability. PLA has begun to develop their joint surveillance system in order to combine Chinese military plan has been presented in East China Sea that are mostly from the naval aviation forces due to the correlation with PLAN aviation force's duty task across the services over the maritime zone. PLA Air Force and PLA Navy have their own independent relations with the coastal radar stations which located under their control territorial (Ying Yu Lin 2016).

\section{The Implementation of Australia's Maritime Defense Strategy in Response toward China's Military Modernization in the Indo-Pacific Region (2013-2016)}

Australia's defense strategy in Indo-Pacific region is to secure Australia's interests is to maintain the rules-based order. The concept of rules-based order itself has been used more broadly than the fundamental aims; to encounter common adviseries in terrorism, natural disasters, and piration. The broader usage of the rules-based order is more into the description of how states should act in international system included the competition forms and the description of the appropriate states' behavior (Robert Farley 2016). Australia's main strategy 
is to modernize the maritime capabilities in a long-term plan, to be able to rich wider range of maritime operation. Bigger vessels and more capability of offshore patrol vessel also have been added to the strategy to help Australia in protecting multiple layers survaillance systems in thes region (ADWP 2016).

Most importantly, Australia has emphasized in one of the three Strategic Defense Objectives, to contribute military capabilities and to have coalition operations that will support Australia's national interests according to the rules-based order. In order to achieve this Australia had tighten the relations with United States as its ally and the elaboration will be in subchapter [4.4] and transform their military capabilities in [4.3]. In this matter, Australia had also grew their military capabilities - particularly the Navy sector in order to secure their national interests that based on rules-based order. Australia has alaso declared that Australia is ready to provide humanitarian assistance in Indo-Pacific when required. For the long-term plan Australia has ensured to maintain ths highest military capability levels of ADF (ADWP 2016)

In order to examine further regarding Australia's defense strategy towards China's emergence in the Indo-Pacific region, the writer uses Neo-realism theory by Kenneth Waltz that has been briefly explained in the first chapter of the research. Neo-realism approach has explained how Kenneth Waltz approaches the real-world problem. As a growing result of traditional realism with its characteristic of balance of power, neo-realism still believe on their older views that war is possible to occur any time. If we relate to the issue-regardless how China keeps emphasizing on "peaceful rise"-Australia is still being aware of the possibility of war that could possibly occur anytime in the region. Neorealist theory stances that competition and conflict among states are under the condition of anarchy; to provide their own security, and threats to their security bound (Jo Jakobsen 2013). In Kenneth Waltz's book "Theory of International Politics" in 1979, Kenneth Waltz has emphasized three main points of his theory which are;
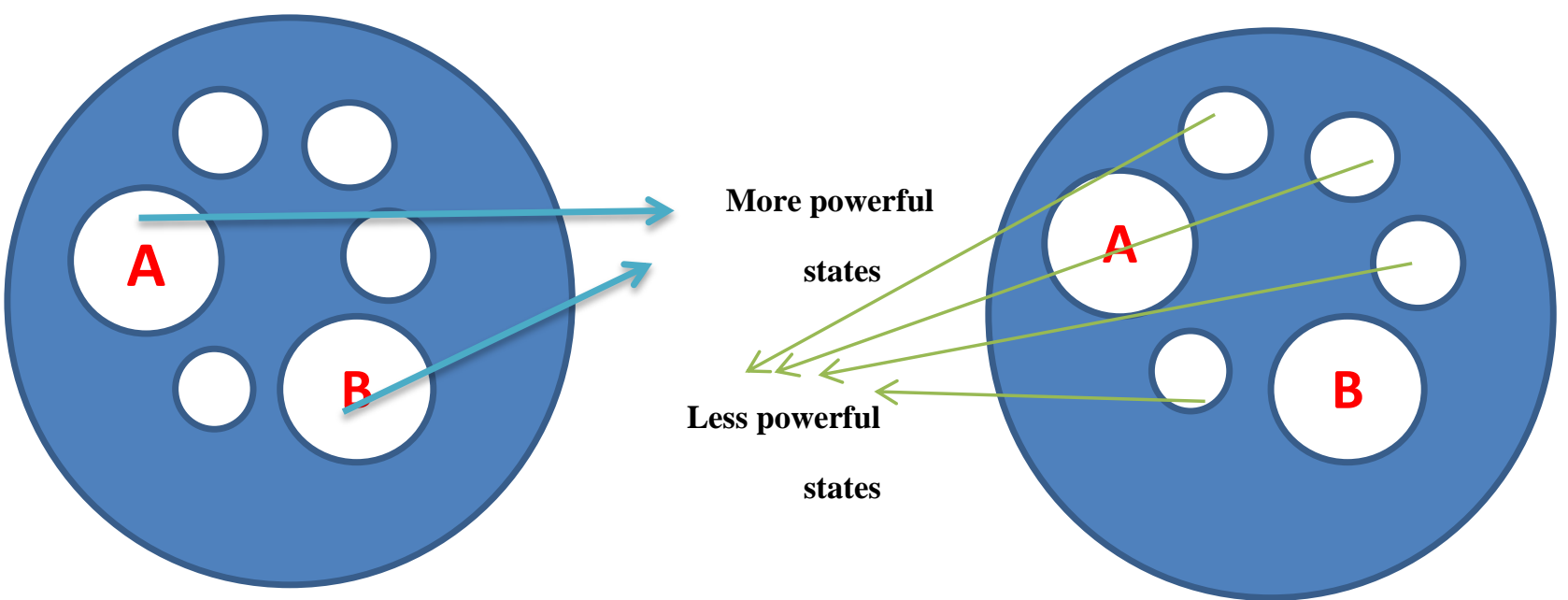

Figure 1. The Anarchic International System (Allen Sens 2012)

The figure 1 shows that in an anarchic international system it is comprised by two kinds of states; more powerful ones and less powerful ones. By this figure we can see through what has happened in Indo-Pacific region, suppose that the two powerful states in the figure are; A is China, B is Australia and the white circles around are the less powerful states in the region. As there is no world government to control as the central authority-in the region, particularly - states in the region are automatically have lack of trust towards each others or just simply insecure that there will be an attack that could harm the peace of their states one 
day in uncertain circumstances. In the anarchic system as well, states are focused more into their own survival, by attaining two primary paces; to increase their military power, or to form alliances (Allen Sens 2012). From the roots itself, the writer believes that China has stareted to modernize their military power due to the reasons mentioned; the lack of trust to othe states in the region, the insecurity of future's probability, the awareness of there is no such world government, yet the disputes of the "nine-dash line" they are having in the region since 1947 have supported China to build up their military capability with pure intention of defending themselves due to the lack of trust and preserve the survival objective track.

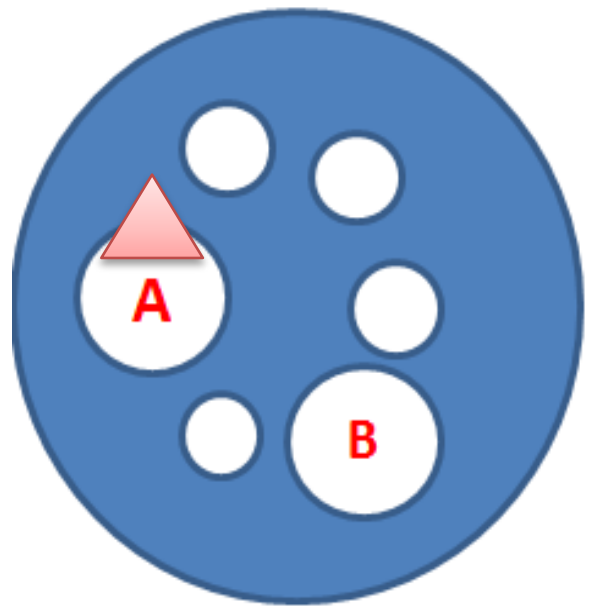

Figure 2. China's Military Modernization in Anarchic Realm

In Figure 2 supposes that China has modernize their military capability, and what has been explained in the third chapter of this research that China has lack of transparency regarding its military modernization plan, strategy, and budget, which somehow lead Australia to wonder the reason why China modernize their military power. Australia has acknowledged China's military modernization and the importance of Indo-Pacific region for their national interests since 2013, even though China keeps emphasizing on their peaceful rise and the defensive nature, Australia has been aware of the existence of attack possibility in uncertain circumstances.

\section{"In an anarchic realm, peace is fragile."}

This powerful quote from Kenneth Waltz is the representation of how peace condition in the world is fragile and it is shown from the fact that many of the countries in China's surrounding including Australia are somehow perceive China's military modernization as foreshadow situation. Anarchic realm that was meant in this quote is the situation where there is no such world government among countries. In anarchic sphere, the condition when one state's contented situation could make other states anxious (Richard K. Betts 2017). Anarchy is the condition of the international system where there is an absence of the central authority. There is nothing such "the world government" to fairly judge whether or not the action or events that occurred because of some states are acceptable. The huge difference between international and domestic political order is the law and the law enforcement itself, in a domestic sphere one person can violates other and the police will attain to sanction the person who violated the law, while in the international sphere has nothing equivalent. By the definition anarchy is the lack of political authority where no sovereign is over the other sovereign (William Spaniel 2012).

In the global politics, it is populated with both powerful states and less powerful states. Therefore the system is anarchic which claimed by two main reason; there is no central 
authority in the system - world government to establish and implement the rules to protect the states in the system - and there is no such strong ruler to control the behavior of states and to enforce the international law to states in the system. The world police is either non-existent or week, with that being said, United Nations. United Nations with its five veto powers are indeed hardly implement the international regulations towards the big five. These conditions caused the states for having insecurities and as a result, states are having a big concern regarding their own survival as their ultimate priority. By the trust issues the states are having towards other states in the system, some states find it hard to establish a long-term cooperation with other states and due to the fact that it is necessary to protect their interests in the international system, states tend to have security dilemma - in which will automatically lead to the build of military power. Nevertheless, when one increased their own military power, one will perceive threaten in a way and will increase their own military capability in response (Alan Sens 2012).

This concept can be applied to the situation where China's military modernization is emerged in the international system particularly in the Indo-Pacific region and how states in the surrounding perceive the military modernization in a various way, specifically Australia. Even though China has emphasized that their military modernization is completely in a defensive way and has no harmful plan towards the surrounding, yet countries still perceive the importance to build their own military capability in order to avoid any harm that could possibly occur by the military modernization in undetermined time. In chapter 2 , it has been explained how China keeps on emphasizing on their peaceful rise for their military development. As fragile as the peace is, all states are still ensuring that peace is the foremost important circumstances they are trying to maintain.

By the system-level story that he has explained, states are always pursuing their selfinterested for their own survival. The fundamental interest of states itself is security. Just as how it applied to personal approach; everyone in the world has the awareness to prior selfhelp in case something unplanned happen instantaneously. Since the awareness of the selfhelp itself, military modernization and that is what the development that pursued by the government all about. The self-help system itself is basically the result from the anarchic world that has been mentioned earlier. States simply believe that they can't rely on other states but themselves for their security. Yet, again, the main purpose of the self-help system itself is in order to survive.

\section{"Where no one commands by virtue of authority, no one is obliged to obey."-Kenneth Waltz, 1979.}

This has a permanent effect to the behavior of the states that became socialized into self-help logic. Kenneth Waltz was trying to refuse the idea of neoliberal regarding the interdependence effect by using two reasons of why anarchic international system limits cooperation which is insecurity and unequal gains (Stanford Encyclopedia of Philosophy 2017). 


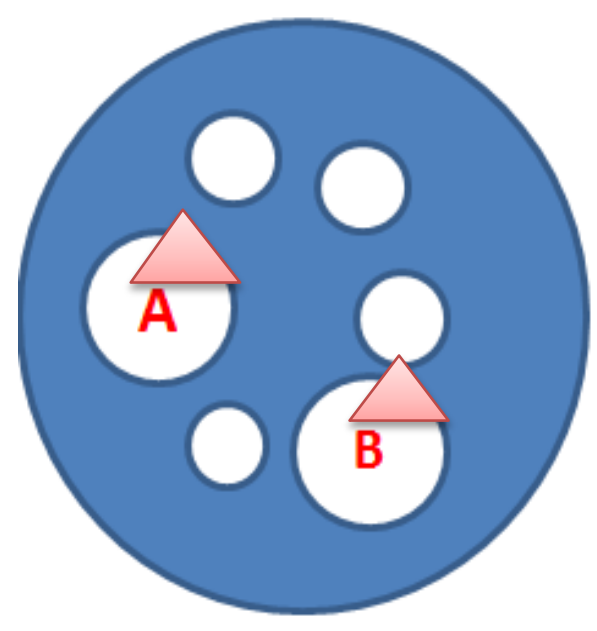

Figure 3. Australia's Self Help System in The Region

As, China [A] has recognized the importance for the state itself to survive by the economic development and having better and bigger military to secure themselves in international realm, Australia [B], has to face numerous global security threats-particularly China's rapid military building in the region in which urge them to have the self-help awareness by building their own military and alliance. Australia has stated that they will embark the largest peacetime upgrade for their armed forces. The rise of the number of Australian naval, air force, and army capability over the last two decades has added more than 62,000 troops to Australian Defense Force which is the largest since 1993 (Simon Benson and Daniel Meers 2016).

The international system is defined by the distribution of power from the number of great powers. By the correlation with the first point, where the international system is anarchic has no central authority to control and manage the behavior of the states, this points will be leading to one of the results of the absence of central authority which the only main actors in the international system are those who have great powers.

Along with the fact of having ten trading partners throughout the region, it is very essential for Australia to unrestrained the trade route. Australia has also initiated better diplomatic relations regarding security issues with Indo-Pacific states in order to secure pursue their interests in a peaceful regard;

\section{- ASEAN Defense Ministers Meeting (ADMM Plus)}

Australia has been actively participated in this meeting. ADMM-Plus is mainly aimed to strengthen partnership particularly regarding defense cooperation for peace, stability, and development in the region throughout dialogue among states; ASEAN member countries, Australia, United States, The Republic of Korea, Russian Federation, China, Japan, New Zealand and India. The purposes are to present mutual trust in defense establishment and to help ASEAN member states to build capacity to address shared security challenges throughout the region (ASEAN.org, n.d). This meeting is basically a discussion among ASEAN member countries and Plus countries regarding security issues yet joint effort in pursuing peace (e.g. peacekeeping operation). 


\section{- $\quad$ East Asia Summit (EAS)}

This summit is mainly promoting regional leaders in cooperation for strategic dialog in facing challenges in East Asia region throughout a forum. The member countries of these summit are included ten ASEAN countries (Indonesia, Brunei, Cambodia, Laos, Malaysia, Myanmar, Singapore, Thailand, Vietnam, and the Philippines), with Australia, China, India, New Zealand, Japan, the Republic of Korea, United States, Russian Federation. In 2016, this summit has discussed regarding the security challenges that have been faced by the member states throughout the region, particularly South China Sea dispute, counter extremism, Korean Peninsula and maritime cooperation (AUS DFAT 2016).

Maritime strategy is very important in defining the military planning, since applies to both areas of coastlines and inland. The main elements of maritime strategy:

1. Sea Denial, is a deterrence strategy that mainly aiming to prevent the usage of the sea by another force. The securement of Australia's offshore territories and facilities are most likely tended to deny the adversary access to the surrounding staging bases. Geographically, the continent with the littoral and maritime approaches has a huge challenge for any kind of potential opponent to overcome (ADWP 2013). For Indo-Pacific region, Australia believes that in the next two decades, the world's submarines will be operated in the region. China, with 70 submarines plan is the main important highlight for Australia. Australia has claimed that they will not take any side in South China Sea dispute, yet in fact Australia has been more focusing on China's military modernization at least for the last two Defense White Papers; 2013, and 2016. Many of states believe that naval blockade is one of the ways to declare war for example if United States, by any circumstances, blockade China's naval to access the aritificial islands, that would automatically assume as "act of war" (Wall Street Journal n.d).

2. Sea Control, is the condition when one has freedom of action to use one particular area for their own purposes in a period of time.

3. Power Projection, is included a broad spectrum of military offensive act. This concept is mainly about the usage of maritime power influence to the land affaris (Australia's Maritime Concept, n.d) Due to the relation with first point, in which Australia needs to protect their territories from any form of adversary; an opponent would need to project power and manage to control the long range to crossing the wide areas, not to mention with the difficulties of the environment to operate, as well as protecting and defending the sustain extended line for supplying the communication. This maritime strategy will bring significant benefits for Australia for the optimized maritime strategy (ADWP 2013).

Australian Navy itself in total has 47 naval assets, 2 aircraft carriers, 11 frigates, 6 submarines, 13 patrol craft, 6 mine warfare vessels (Global Fire Power, 2017). The 2016 ADWP predicted that in 20 years, half of the world's submarines will be operating in IndoPacific region since there are many states in the region are obtaining submarines. Australian Navy will continue the partnership with the US Navy in enhancing the maritime capabilities. (Diana Edwards 2016).

Sea power is a fundamental yet decisive factor in maritime security. Corbett's maritime strategy comprised that maritime strategy is an extension of the strategy of land, as well as serving the strategy. His theory also covered not only naval operations but also national policy. He believes that national policy objectives should be set in consonance with the maritime strategic objectives. He believes that maritime strategy has larger circumstances of international affairs. Sea power was believed as the sine qua non of the greatness of a nation (William R. Sprance 2004). 


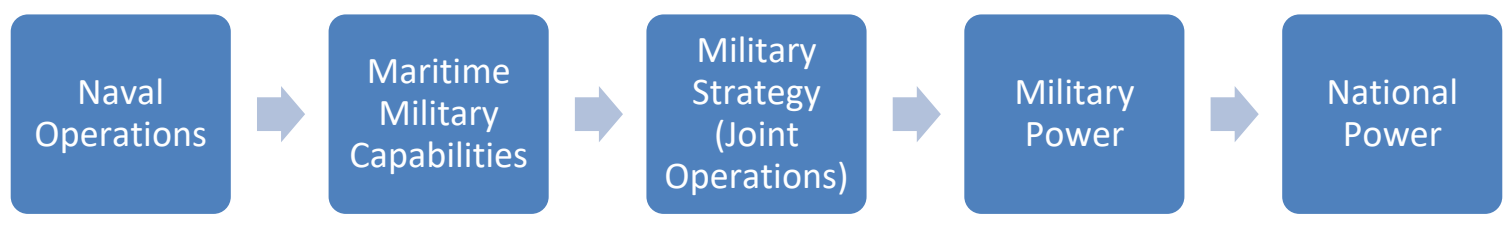

Figure 4. Sea Power as input to National power development (Indra Alverdian 2017)

Figure 4 shows that from this concept we can see how Australia's naval operations has affected the maritime military capabilities that will lead to the awareness of the importance of military strategy and as when it turns into a greater military power, the national power is automatically being greater. According to one of his book that published in 1911 entitled "Principles of Maritime Strategy", Corbett explained that maritime dominance lies in the effective use of the sea lines in order to maintaining communications and denying that use to the enemy (Corbett 1911). In this book he divides his theory into three main focuses;

1. Command of the sea, which refers to the control of maritime communication whether commercial or military purposes. As the world's busiest economic corridor, Australia government will engage with other countries in order to strengthen the regional security (ADWP 2013). In order to stregthen the navy's command of the sea Australia has added more vessels in order to maintain the critical role in protecting Australia's security in the region. These vessels are highly integrated with the enhancement of the circumstantial awareness, as well as for the communication and data sharing tools among maritime, air, and land-based systems which will be very useful for Australia's wider range of the whole government prior included; search and rescue, humanitarian assistance, to search and rescue, and for the disaster relief operations in the region and beyond (ADWP 2016). The writer believes this is the respond to China's major plan to defend their communication line both for military and trade in the sea. As the main interests of China is to safeguard the energy security interests, it is very fundamental for China to protect the transportation and communication of sea lanes from Bab-el-Mandeb, Hormuz, to Malacca Strait (Linda Jakobson 2015).

2. Constitution of fleets, that explains power of implementing the control; the better and the more numerous the application for commerce and transports, the weaker the fighting power will be. Australia's plan to modernize their maritime capability has been explained in details in the 2016 Defense White Paper including the addition plan of more naval power. More capable offshore vessels with high endurance, higher capacity, and greater range ability will be added, plus new aircraft for the maritime surveillance system both manned and unmanned ones. For the submarines, the amount will be doubled, which will be 12 and by 2035 Australia has planned around half of the submarines will be operated in Indo-Pacific region where Australia's most vital interest located. The future submarines will be completed with advanced facilities and port facilities that will make the submarines similar with Collins Class submarines and upgraded into AN/BYG-1 combat system as well as Mark 48 MOD 7 (ADWP 2016). The writer believes this respond is due to the fact that China, in 2014, has already had 255,000 sailors; 1 aircraft carrier, 70 submarines; 29 destroyers; 49 frigates, 86 landing crafts, 39 minesweepers, and 368 coast defense ships with the keep increasing 
number which are ready to be deployed in the region anytime possible. (China Today 2014)

3. Concentration and dispersal of force, which was emphasizing on strategy that often described as the art of assembling the force at the right circumstances. Australian government has improved the maritime and land forces by deploying land-based-antiship missiles to protect the national energy assets. For the missile defense, Australia has been aware of the threat of ballistic and cruise missile that occurred in IndoPacific region, even though there is only low possibility for Australia to get attacked by ballistic missile, Australia will be tighten the relations with United States regarding the ballistic missile issue. For the amphibious operations for the support the strategy in Southeast Asia, Pacific island countries and to address threats in the Indo-Pacific region, the two HMAS Canberra and HMAS Adelaide will be operated in the region (ADWP 2016). The writer believes that this is the respond to China's main goal for the military modernization to emphasize China's claim in South China Sea (SCS) and East China Sea (ECS). The rich fisheries and energy resources, as well as the strategic transport routes, China's claims are basically emphasizing the soverignty over territorial features (ISDP 2016). As the global wealth and the power shift keep developing in the region, China's interests in Indo-Pacific are different in various important ways; particularly, the Indian Ocean-China keeps seeking the protection for their energy supplies and the opportunity to project power (Linda Jakobson 2015).

As inputs, sea power is the contribution of the navy coast guards, maritime industries towards the maintenance and the development of national power. As the outputs, it is more about how it influences the events on land. Corbett offered that a prolonged defensive deadens the offensive spirit, which is why security is very important. It is according to the importance of command of the sea to protect national trade. He was also emphasizing that concentration was a more flexible concept (Matt Domsalla 2010).

Australia has also strengthen the bilateral relations with United States in order to encounter the emergence of China in Indo-Pacific region. Historically, after the Second World War, there was a shift in the political and economic pattern that caused by the great depression and the war aftermath. The British Foreign and Commonwealth Office were established to expand Australian expansion overseas, and in the early 1943, the US Embassy opened in Canberra (F.K. Crowley 1973). For the military sector, during the Second World War, General Douglas MacArthur was deployed to lead the Allied Forces in the South West Pacific Area, which at that time comprised numerous Australian troops. Then ANZUS treaty established and ratified by Australia, New Zealand and United States and Australia has contributed of major American military endeavors ever since.

As China's Navy capability is now the biggest all round Asia, and the submarines by 2020 is aproximately will be more than 70 submarines, as well as the more techonological command, forces, and cyber capabilities China is building, Australia assumed that along with the grows, China will seek greater influence in the region. Australia believes that both the government of China and United States already cooperated in various security areas; joint exercise, humanitarian assistance, etc. As well as lately the relations between the two has been increased by the defense dialogue and the development of bilateral mechanism to increase China's transparency to decrease any kind of misunderstanding or trust issues. The relations of the three are keep harmonizing by the dialogue in the region such as ADMM-Plus and ASEAN Regional Forum. If the relations between United States and China keeps harmonize by day, indeed the big conflict among the two giants are improbable. For Australia, the implication of the alliance with the United States in China's military modernization is basically the shared values and the ongoing plan to be the highlight of both countries' defense policies. 
The Five Power Defense Arrangement is a multilateral defense relation between Australia, United Kingdom, Malaysia, Singapore and New Zealand. Historically, his arrangement has been ratified in 1971 by the five states mentioned that stated the cooperation among the five if there will be attack from the outsider. One decade after the ratification, the five states held an annual exercise for the army and since 1997 they already have join military exercise between their sea and air. The five major powers have changed the diplomacy in the international system with creating alliance, maintaining it, and disrupted. Together with the other four countries, this cooperation has become the longest standing mechanism to secure the region. Especially, FPDA is the only multilateral security in the region that has main focus on any kind of operation in the Southeast Asian region, as well as the cooperation has been important for foster Australia's efforts to advance their interests in Southeast Asia, yet particularly to pursue the Indo-Pacific interests (ADWP 2016).

In 2016, Australian warships, troops and aircrafts have arrived in South China Sea region to begun the joint military exercise with FPDA which was hosted by Singapore. The contribution of Australia was the arrival of the HMAS Warramunga, 12 F/A-18A Hornest, and numerous patrol aircraft (Andrew Greene 2016).

Australia claimed that this joint operationis aimed to enhance the operability of FPDA members and to have wider understanding and knowledge regarding each other's tactics and operational positions. The writer believes, as the location is exactly in the heart of China's main interests, this joint military exercise is one of Australia's response towards China's military modernization in the region.

\section{Conclusion}

Indo-Pacific region has grown into the most important region in the world. As a maritime realm, Indo-Pacific region provides the connection of Indian and Pacific Oceans, from Korean Peninsula to Persian Gulf crossing the heart of South-East Asia are immensely a lot to offer. Along with the dynamics of the region, more and more states have started to concentrate their national interests in the region. Australia, particularly, as a state that located exactly near the heart of the region, Indo-Pacific has become one of their most important strategic defense interests. Due to the fact that geography is extremely vital as state's fundamental aspect in pursuing power, Australia has been aware of the urgency to maintain Indo-Pacific regional security. Australia believed that the biggest challenge in maintaining the regional stability is the emergence of military modernization in the region.

China's rapid economic growth in the last decades has supported China's urge to develop their military capability. China has claimed their peaceful rise and has emphasized that their military modernization is opposing the idea of seeking hegemony and expansion in order to ensure that other states would not be insecure with their development. Yet, China provided lack of transparency strategy and official documents, in which lead other statesparticularly Australia - that has important national interests in the region perceived that the military modernization could turn from defensive to offensive act anytime possible. Australia's Defense White Paper from 2013 until 2016 has seriously solemnly examine the importance of China's military modernization in Indo-Pacific to Australia's maritime security in the region. Not to mention, the disputes that was still happening in the South China Sea, and the lack of official information and publicity of China's military modernization has created such big insecurities for Australia.

China, on the other hand, has also considered their maritime environment as their vital national interest. The idea of Maritime Silk Road Initiative has initially crossing the Indian Ocean and South China Sea at once. The strong economy relations among China and states in the region included Australia has brought the confidence to China that the states mentioned 
would not bother the risk of their relations over the vague worries since China kept emphasizing their positive and peaceful rise in the region. Along with high rise of the military budget, China's naval power in the region has grown into a massive super power. The capabilities and size has been improved over the decade. The modernization of submarines, cruises missiles and aircraft have immensely supported of the modernization of PLAN.

In response, Australia has stated multiple times in both 2013 and 2016 Defense White Paper regarding the main interests of Australia in the Indo-Pacific, the emergence of military modernization and most importantly Australia has addressed China's significant military modernization will be the biggest challenge in stabilizing the security of Indo-Pacific region, particularly in the maritime sector. In 2013, Australia has emphasized that Australia's prosperity is highly related with the maritime routes of Indo-Pacific region. Australia has also underlined that in order to maintain the security of the region, Australia would keep upholding the value of rules-based order. Australia has strengthened the relations among ASEAN states and other major powers in the region through discussion and joint military exercise.

For the maritime implementation itself, the writer believes that Australia has used the concept of Sea Denial, Sea Control and Power Projection concept. The Sea Denial concept they used condemn any kind of adversary access that come nearby Australia's offshore territories. Australia used their advance maritime technology in the region as the Sea Control implementation and protected the extended line to supply communication and to have wider range in crossing the areas which was the implementation of the power projection. Australia had also their biggest expansion of Navy ever since the aftermath of the Second World War by having the plan of five thousand more personnel to be recruited, 12 new submarines that was doubled from the previous amount, 12 combat patrol vessels and 9 antisubmarine frigates. The writer believes the main reason of Australia's awareness of the military modernization had increased by the presence of China in the region. 9 antisubmarine frigates are supposed to be useful to minimize China's 70 submarines capability in the region.

Australia had also implemented their maritime strategy by controlling their maritime communication, as the important key of military and trade in the sea from Bab-el-Mandeb, Hormuz to Malacca Strait. As well as added more fighting vessels to the defense plan to encounter China's possibility of offensive behavior in uncertain future circumstances and by deploying land-based-anti-ship missiles to protect Australia's national energy assets. Australia had also strengthen the bilateral relations with United States to encounter the emergence of China's military modernization in the region. As well as strengthening Australia's alliance with Five Defense Arrangements members to secure Indo-Pacific maritime sector from any possible adversary. 


\section{REFERENCES}

\section{Books}

Klein, Natalie. 2015. Maritime Security and the Law of the Sea. Oxford: Oxford University Press.

Betts, Richard K. 2017. Conflict after the Cold War: Arguments on Causes of War and Peace. Blanchard, Jean-Marc F. 2018. China's Maritime Silk Road Initiative and South Asia: A Political Economic Analysis of Its Purposes, Perils, and Promise.

\section{Government Documents}

Australia. 2013. Australian Defense White Paper. http://www.defence.gov.au/whitepaper/2013/docs/WP_2013_web.pdf

Australia. 2016. Australian Defense White Paper. http://www.defence.gov.au/WhitePaper/Docs/2016-Defence-White-Paper.pdf

Australian. 2017. Australian Parliament Publication. https://www.aph.gov.au/Parliamentary_Business/Committees/Senate/Foreign_Affairs_ Defence_and_Trade/Completed_inquiries/2004-07

China. 2014. China's Ministry of Defense Publication. http://eng.mod.gov.cn/publications/2016-07/13/content_4768294.htm

Australia. 2010. Australian Maritime doctrine. http://www.navy.gov.au/sites/default/files/documents/Amd2010.pdf

Australia. 2016. Australian Department of Foreign Affairs and Trade. http://dfat.gov.au/international-relations/regional-architecture/eas/Pages/east-asiasummit-eas.aspx

China. 2013. Information Office of the State Council the People's Republic of China Publication. http://english.gov.cn/

Evans, Michael. Australian Navy. 2016. "Australian Rendezvous: Maritime Strategy and National Destiny in the 21st Century". http://www.navy.gov.au/sites/default/files/documents/Soundings_Paper_No_12.pdf

\section{Journals}

Raska, Michael. 2015. "Military Transformations Program Institute of Defense and Strategic Studies." Strategic Transformation and Military Modernization in the Asia-Pacific Region."

Dibb, Paul. 2006. "Is strategic geography relevant to Australia's current defense policy?" Australian Journal of International Affairs 60.

Tayloe, Shane C. 2017. "Crossover Point: How China's Naval Modernization Could Reverse the United States' Strategic Advantage." Journal of Asian Security and International Affairs 4, no. 1.

Scott, D. 2013. "Australia's embrace of the 'Indo-Pacific': new term, new region, new strategy?" International Relations of the Asia-Pacific 13, no. 3.425-448. doi:10.1093/irap/lct009.

Taneja, Pradeep. 2014. "Australian and Southeast Asian Perspectives on China's Military Modernization." Journal of Asian Security and International Affairs 1, no. 2, 145-162. doi:10.1177/2347797014536637. 


\section{Lectures Materials}

Perwita, A.A. Banyu. 2017. National Security is Inevitable with the Existence of Threat Perception.

Alverdian, Indra. 2017. Sea Power As Input To National Power Development.

\section{Newspapers/Online}

ChinaPower Project. 2017. "What Does China Really Spend on Its Military?". Last modified August 4. https://chinapower.csis.org/military-spending/.

Rani D. Mullen and Cody Poplin. 2015. "The New Great Game." Foreign Affairs. Last modified September 29. https://www.foreignaffairs.com/articles/china/2015-0929/new-great-game.

The Economist. 2013. "The Military Balance." Last modified March 18, 2013. https://www.economist.com/blogs/graphicdetail/2013/03/daily-chart-11.

MinghaoZhao. The Diplomat. 2013. "The Emerging Strategic Triangle in Indo-Pacific Asia." The Diplomat. Last modified June 4. https://thediplomat.com/2013/06/the-emergingstrategic-triangle-in-indo-pacific-asia/.

Mercy A. Kuo and Angelica O. Tang. 2016. The Diplomat. "Chinese Grand Strategy: Interests, Institutions, Influence." The Diplomat. Last modified January 6. https://thediplomat.com/2016/01/chinese-grand-strategy-interests-institutionsinfluence/.

International Institute for Strategic Studies | IISS. 2018. "Asia-Pacific Regional Security Assessment 2015." Accessed on 5. https://www.iiss.org/en/publications/strategic\%20dossiers/issues/asia-pacificregional-security-assessment-2015-4c79.

Michael Evans. Royal Australian Navy. 2018. Accessed on February 5. http://www.navy.gov.au/sites/default/files/documents/Soundings_Paper_No_12.pdf.

The American Interest. 2017. "The Indo-Pacific: What's in a Name?" Last modified July 20. https://www.the-american-interest.com/2013/10/10/the-indo-pacific-whats-in-aname/.

Blumenthal, Dan. 2013. "A Sino-America Proxy War?" China-US Focus. https://www.chinausfocus.com/foreign-policy/a-sino-america-proxy-war.

Medcalf, Rory. The Diplomat. 2013. "Breaking Down Australia's Defense White Paper 2013." The Diplomat. Last modified May 7. https://thediplomat.com/2013/05/breaking-down-australias-defense-white-paper$2013 /$.

Holmes, James R. The Diplomat. 2011. "From Mahan to Corbett?" The Diplomat. Last modified December 11. https://thediplomat.com/2011/12/from-mahan-to-corbett/.

Domsalla, Matt. 2018. "Hattendorf, Mahan On Naval Strategy (XXI)." SAASS Comps Prep Wiki.

Accessed

February

http://saass.wikia.com/wiki/Hattendorf,_Mahan_On_Naval_Strategy_(XXI).

Bateman, Sam. 2006. "The Emergent Maritime Future of the Asia-Pacific Region." The Evolving Maritime Balance of Power in the Asia-Pacific 239-252. doi:10.1142/9789812773425_0012.

Brewster, David. 2016. "The Indo-Pacific Century." Policy Forum. Last modified December 19. https://www.policyforum.net/indo-pacific-century/. 
D. Wilson, Jeffrey. 2018. Perth USAsia - Home. Accessed February 7. http://perthusasia.edu.au/getattachment/be3d8ec4-50f2-4e4d-8c4b46943500f726/PU-27-IPIS-8-WEB-170817.pdf.aspx?lang=en-AU.

Gopal, Prakash. 2017. "Maritime Security in the Indo-Pacific: The Role of the US and Its Allies." Taylor \& Francis. Last modified May 22. http://www.tandfonline.com/doi/abs/10.1080/09733159.2017.1321208.

Medcalf, Rory and Raja Mohan. 2014. Responding to Indo-Pacific rivalry: Australia, India and middle power coalitions. https://www.lowyinstitute.org/publications/respondingindo-pacific-rivalry-australia-india-and-middle-power-coalitions

Altincekic, Ceren. 2016. "Summary of "Theory of International Politics"." Beyond Intractability. Last modified June 18. https://www.beyondintractability.org/bksum/waltz-theory.

Jakobsen, Jo. 2013. "Neorealism in International Relations - Kenneth Waltz." POPULAR SOCIAL SCIENCE. Last modified November 5. http://www.popularsocialscience.com/2013/11/06/neorealism-in-internationalrelations-kenneth-waltz/.

ISEAS, Zhao Hong. 2016. "China's Maritime Silk Road Faces a Wave of Challenges." East Asia Forum. Last modified 15. http://www.eastasiaforum.org/2016/12/16/chinas-maritime-silk-road-faces-a-waveof-challenges/.

M. Warner, Robin. Research Online - University of Wollongong. Accessed February 8. http://ro.uow.edu.au/cgi/viewcontent.cgi?article=1599\&context=lawpapers.

Zand, Benhard. 2016. SPIEGEL ONLINE, Hamburg, Germany,. "The Maritime Silk Road: China's High Seas Ambitions - International." SPIEGEL ONLINE. Last modified September 8. http://www.spiegel.de/international/world/china-increasing-overseasambitions-with-maritime-silk-road-a-1110735.html.

Sens, Alan. 2012. Anarchic International System. https://www.youtube.com/watch?v=r_Gm79wstmY\&list=PLKO5B8Arxz4pePVINq NM3j94sIFOHMLN_\&index=2

Lockie, Alex. 2016. Business Insider US. "How China's Navy Rapidly Modernized to Rival the US's." Business Insider Singapore. Last modified June 18. http://www.businessinsider.sg/how-china-has-modernized-their-navy-2016$6 / ? \mathrm{r}=\mathrm{US} \& \mathrm{IR}=\mathrm{T}$.

Statista. 2018. "China's Expenditure on Military Services 2016 | Statistic.". Accessed February 8. https://www.statista.com/statistics/267035/china-military-spending/.

Wood, Peter. 2017. "China's Northern Theater Command." Last modified March 9. https://www.p-wood.co/2017/03/09/chinas-northern-theater-command/.

Lague, David. 2018. "Breakout: Inside China's Military Buildup." Reuters. Accessed February 8. https://www.reuters.com/investigates/china-military/.

L. Shapiro, Jacob. 2017. "The Coming Conflict Between China and Japan." Geopolitical Futures. Last modified December 5. https://geopoliticalfutures.com/coming-conflictchina-japan/.

Mukherjee, Kunal. 2017. "Assessing Security Relations in the Asia Pacific: the Cases of China, India and Pakistan." Taylor \& Francis. http://www.tandfonline.com/doi/abs/10.1080/11926422.2017.1331174.

Pike, John. 2018. "Military Power of the People's Republic of China - China's Critical Sea Lanes." GlobalSecurity.org - Reliable Security Information. Accessed February 8. https://www.globalsecurity.org/military/library/report/2007/2007-prc-militarypower_fig01.htm. 
Pike, John. 2011. "People's Liberation Navy Costal Defense Org. Structure." GlobalSecurity.org - Reliable Security Information. Last modified November 7. https://www.globalsecurity.org/military/world/china/plan-cdf-org.htm.

Farley, Robert. 2016. "How the Rules-Based Order Really Works in Asia." The Diplomat. Last modified September 12. https://thediplomat.com/2016/09/how-the-rules-basedorder-really-works-in-asia/.

Lin, Ying Yu. "The Implications of China's Military Reforms." The Diplomat. Last modified March 7, 2016. https://thediplomat.com/2016/03/the-implications-of-chinas-militaryreforms/.

Hongzhou, Zhang. 2018. "Rethinking China's Maritime Militia Policy (PDF Download Available)." ResearchGate. Accessed 8. https://www.researchgate.net/publication/291338832_Rethinking_China's_Maritime_ Militia_Policy.

Global Firepower. 2017. Australia Military Strength." Global Firepower - 2017 World Military Strength Rankings. Accessed 9. https://www.globalfirepower.com/country-military-strengthdetail.asp?country_id=australia.

ASEAN. 2018. "ADMM-Plus - ASEAN Defence Minister's Meeting (ADMM)." ADMM, ASEAN Defence Ministers Meeting. Accessed February 9. https://admm.asean.org/index.php/about-admm/about-admm-plus.html.

Edwards, Diana. 2018. "Australian Shipbuilding: Addressing Indo-Pacific Concerns?" Canadian Naval Review. Accessed February 9.. http://www.navalreview.ca/wpcontent/uploads/public/Vol12num3/Vol12num3art7.pdf.

ASEAN. 2018. "East Asia Summit (EAS)." ASEAN | ONE VISION ONE IDENTITY ONE COMMUNITY. Accessed February 9, 2018. http://asean.org/asean/externalrelations/east-asia-summit-eas/.

Benson, Simon and Daniel Meers. 2016. https://www.dailytelegraph.com.au/technology/defence-force-upgrade-australia-willbe-armed-to-the-teeth-under-new-government-plan/newsstory/8a0d820e950f80fc042346fc218bf162.

Bisley, Nick. 2011. "Australia in Asia: How to Keep the Peace and Ensure Regional Security." The Conversation. Last modified October 10. http://theconversation.com/australia-in-asia-how-to-keep-the-peace-and-ensureregional-security-3592.

Parliament of Australia. 2018. "Defence Budget Overview - Parliament of Australia.". Accessed January 23, 2018. https://www.aph.gov.au/About_Parliament/Parliamentary_Departments/Parliamentar y_Library/pubs/rp/BudgetReview201314/DefenceBudget.

Taylor and Francis. 2017. "Economic Growth and Demand for Military Expenditure in the Indo-Pacific Asia Region." Last modified January 8.http://www.tandfonline.com/eprint/D7z7FvHcGYBnyvES5yap/full.

Pike, John. 2017. "Australia - Military Spending." GlobalSecurity.org - Reliable Security Information. Last modified August 3. https://www.globalsecurity.org/military/world/australia/budget.htm.

Research Online - University of Wollongong. 2018. Accessed January 23. http://ro.uow.edu.au/cgi/viewcontent.cgi?article=1433\&context=lawpapers.

ASEAN Regional Forum. 2018. Accessed January 23. http://aseanregionalforum.asean.org/files/library/ARF\%20Defense\%20White\%20Pap ers/China-2013.pdf. 
Geoscience Australia. 2014. "Australia's Maritime Jurisdiction Map Series - Geoscience Australia." Last modified 5. http://www.ga.gov.au/scientifictopics/marine/jurisdiction/map-series.

Australia. 2018. "Budget Paper No.2: Budget Measures - Part 3: Capital Measures - Defence." Budget 2017-18. Accessed January 23. http://www.budget.gov.au/201415/content/bp2/html/bp2_capital-02.htm.

East Asia Forum. 2016. "China's Maritime Silk Road Faces a Wave of Challenges.". Last modified December 15. http://www.eastasiaforum.org/2016/12/16/chinas-maritimesilk-road-faces-a-wave-of-challenges/.

The State Council of the People's Republic of China. 2015. "China's Military Strategy (full Text)." Last modified 27. http://english.gov.cn/archive/white_paper/2015/05/27/content_281475115610833.htm

Parliament of Australia. 2018. "Defence Budget Overview - Parliament of Australia." Accessed January 23, 2018. https://www.aph.gov.au/About_Parliament/Parliamentary_Departments/Parliamentar y_Library/pubs/rp/BudgetReview201415/DefenceBudget.

Central Tibetan Administration. 2018. "Eye on India, China Raises Tibet Military Command Rank." Accessed January 23. http://tibet.net/2016/05/eye-on-india-china-raises-tibetmilitary-command-rank/.

Daily Telegraph. 2016. "Fortress Australia: Armed to the Teeth." | We're for Sydney. Last modified February 26. https://www.dailytelegraph.com.au/technology/defence-forceupgrade-australia-will-be-armed-to-the-teeth-under-new-government-plan/newsstory/8a0d820e950f80fc042346fc218bf162.

Joshi, Manoj. 2018. "China's Military Modernisation and Its Implications." ORF. Accessed January 23. http://www.orfonline.org/expert-speaks/chinas-military-modernisationand-its-implications/.

Indo-Asia-Pacific Defense Forum. 2018. "Maritime Modernization". Accessed January 23. http://apdf-magazine.com/maritime-modernization/.

Routledge.com. 2009. "Maritime Security: International Law and Policy Perspectives from Australia and New Zealand (e-Book) - Routledge.". Last modified October 16. https://www.routledge.com/Maritime-Security-International-Law-and-PolicyPerspectives-from-Australia/Klein-Mossop-Rothwell/p/book/9780203867471.

Mitter, Rana. 2013. "Opinion | The World's Wartime Debt to China." The New York Times Breaking News, World News \& Multimedia. Last modified October 17. http://www.nytimes.com/2013/10/18/opinion/the-worlds-wartime-debt-to-china.html.

Foreign Affairs. 2015. "The New Great Game." Last modified September 29. https://www.foreignaffairs.com/articles/china/2015-09-29/new-great-game.

Perlez, Jane. 2016. "Australia Announces Rise in Spending for Military." The New York Times - Breaking News, World News \& Multimedia. Last modified February 24. https://www.nytimes.com/2016/02/25/world/australia/australia-announces-rise-inspending-for-military.html.

Pike, John. 2011. "People's Liberation Navy Costal Defense Org. Structure." GlobalSecurity.org - Reliable Security Information. Last modified November 7. https://www.globalsecurity.org/military/world/china/plan-cdf-org.htm.

Geopolitical Futures. 2017. "Power and Ideology: China's Cultural Revolution." Last modified May 11. https://geopoliticalfutures.com/power-and-ideology-chinascultural-revolution/.

Europarl. 2018. "The Role of the Army in China's Politics Think Tank." Accessed January 23. http://www.europarl.europa.eu/thinktank/en/document.html?reference=EPRS_BRI(20 15)564375. 
N. Pham, Tuan. 2018. The Diplomat. "China in 2018: What to Expect." The Diplomat. Last modified January 11. https://thediplomat.com/2018/01/china-in-2018-what-toexpect/.

South China Morning Post. 2018. "Xi Calls for Battle Readiness As Troops Stage Massive Winter Drills." Last modified 18. http://www.scmp.com/news/china/diplomacy-defence/article/2126899/xi-jinpingcalls-battle-readiness-troops-stage-massive.

Lin, Ying Yu. 2016. The Diplomat. "The Implications of China's Military Reforms." The Diplomat. Last modified March 7. https://thediplomat.com/2016/03/the-implicationsof-chinas-military-reforms/.

Sina.com. 2018. "详解五大战区范围 : 战区陆军司令部独立驻扎" 军事频道_最多军迷首 选的军事门户_新浪网. Accessed January 23. http://mil.news.sina.com.cn/china/2016-02-11/doc-ifxpmpqt1067293.shtml. 